\title{
Selection for prolificacy in Finnsheep and in Norwegian sheep
}

\author{
T. ÅDNØY \\ Department of Animal Science, Agricultural University of Norway, \\ Box 25, 1432 Ass-NLH, Norway
}

\begin{abstract}
Litter size (LS) at birth and other production traits were recorded for Finnsheep (F), Norwegian (N) breeds Dala (D), Steigar (St) and Spael (Sp), for N sheep crossed with 1/4 $\mathrm{F}$ and $1 / 2 \mathrm{~F}$ and for a group of sheep established by collecting offspring of highly prolific $\mathrm{N}(\mathrm{N}+)$ ewes. The $\mathrm{N}$ breeds and the $1 / 4 \mathrm{~F}$ group were part of the national breeding scheme. In the $1 / 2 \mathrm{~F}$ and $\mathrm{N}+$, selection was solely for LSB. The other groups were selected normally. There were $\mathbf{4 2 6 3}$ lambings. In adults, there were no breed group differences in lambing- $\%$ (mean $94 \%$ ), but in 1-yr. olds there were differences: Sp $90 \%$, F and F-crosses 80-85 \%, D $70 \%$, $\mathrm{N}+60 \%$ and St $50 \%$.

F-crosses had clearly the best LS's (F ca. 3.0, 1/2 F 2.4, 1/4 F 2.0). Those of N + decreased through the 5 years recorded from near 2.0 to 1.8 lambs. The other breed groups gave LS's of 1.7-1.8. In the two groups selected for LS, no selection response was found. The reasons are not known.

Although the pure $\mathrm{F}$ and $1 / 2 \mathrm{~F}$ gave lower weaning weights ( 34 and $38 \mathrm{~kg}$ at $150 \mathrm{~d}$.) than the other groups $(41-45 \mathrm{~kg}$ ), their weaned lamb yield per ewe was ca. $20 \mathrm{~kg}$ higher. Considering the poorer carcass quality observed in earlier experiments for these groups, the use of $1 / 4$ $\mathrm{F}$ is recommended for Norwegian conditions. This breed group gave no reduction in weaning weight, but increased the LS by some 0.2 lambs.
\end{abstract}

Index words: Finnsheep, Norwegian breeds, litter size, synthetic, lambing-\%, weaning weight

\section{Introduction}

Finnsheep (F) were imported to Norway in 1967 and in 1972. They were tried in crosses with Norwegian $(\mathrm{N})$ breeds and with Texel and Suffolk $(3,2)$. It was concluded that use of $1 / 2$ or $1 / 4 \mathrm{~F}$ gave a $10-30 \%$ higher production per ewe, and that for practical sheep breeding in Norway the use of $1 / 4 \mathrm{~F}$ could be recommended.

An alternative way to increase lamb number would be to select for it. It was felt, taking into consideration the results of experiments in New Zealand and Australia, that it might be possible to increase the number of lambs per ewe by directly and solely selecting 
for this purpose. This has been done both for groups of $\mathrm{N}$ sheep and for synthetic lines of sheep containing about $1 / 2 \mathrm{~N} 1 / 2 \mathrm{~F}$.

\section{Materials and methods}

From 1971 onwards our department in cooperation with the Tjøtta Research Station established lines of sheep by buying lambs of highly fertile ewes. The ewes were found in two counties, Nordland and Hordaland, by screening the national sheep recording data, and the lambs were placed at Tjøtta and at Rosendal sheep research farm. The ewes were required to have at least 3 years' lambing records and an average age-adjusted litter size (LS) at birth of minimum 0.5 above flock average (1).

These groups and two synthetic groups of $1 / 2 \mathrm{~F} 1 / 2 \mathrm{~N}$ sheep placed at Tjøtta and at the Sæter Research Station, were selected for LS at birth throughout the experiment, which ended in 1986.

Other breed groups were kept at the same three stations and are used as comparisons: the N-breeds, Dala (D), Steigar (St) and Spæl (Sp); pure F; and 1/4 F. The comparison groups were bred according to the national breeding scheme by using its indexes, rams, etc.

The numbers of ewe-years recorded in the years $1982-86$ are given in table 1 per breed group and research station. Only Tjøtta had all breed groups represented and only D and $1 / 4 \mathrm{~F}$ groups are at all three stations.

For the three stations 4999 ewe-years were recorded, mainly by the national sheep control. Of these 4687 were available for this analysis.

\section{Percent of ewes lambing}

The proportion of ewes lambing in each breed group is shown in table 2 .

There were not found any significant breed differences for ewes two years and older, the overall proportion giving lambs being $96 \%$, whereas for the one-year-olds differences were
Table 1. Number of ewe-year records in 1982-86.

\begin{tabular}{lccrr}
\hline Breed group & Rosendal & Sæter & Tjøtta & Total \\
\hline Dala & 437 & 602 & 271 & 1310 \\
Steigar & - & - & 325 & 325 \\
Selected N & 313 & - & 397 & 710 \\
1/4 F & 239 & 590 & 346 & 1175 \\
Selected 1/2 F & - & 270 & 271 & 541 \\
Finnsheep (F) & - & 61 & 93 & 154 \\
Spæl & - & 182 & 290 & 472 \\
\hline Total & 989 & 1705 & 1993 & 4687 \\
\hline
\end{tabular}

Table 2. Lambing results.

\begin{tabular}{lcccccc}
\hline & \multicolumn{2}{c}{$\begin{array}{c}\text { Proportion of } \\
\text { ewes lambing }\end{array}$} & & \multicolumn{2}{c}{$\begin{array}{c}\text { Number of } \\
\text { lambs born }\end{array}$} \\
\cline { 2 - 3 } \cline { 6 - 7 } & LS-mean & Mean & & LS-mean & Mean \\
\hline Dala & 0.90 & 0.90 & & 1.82 & 1.83 \\
Steigar & 0.84 & 0.80 & & 1.72 & 1.75 \\
Selected N & 0.87 & 0.88 & & 1.93 & 1.97 \\
1/4 F & 0.93 & 0.94 & & 2.02 & 2.04 \\
Selected 1/2 F & 0.94 & 0.94 & & 2.45 & 2.50 \\
Finnsheep (F) & 0.93 & 0.93 & & 3.07 & 3.08 \\
Spæl & 0.96 & 0.95 & & 1.81 & 1.86 \\
\hline
\end{tabular}

significant. Sp and the three $\mathrm{F}$ groups gave more easily lambs at one year of age than did the three other $\mathrm{N}$ breed groups. The results are shown in figure 1.

\section{Number of lambs per lambing}

Through the five-year period $(1982-86)$ 4263 lambings were recorded.

Data for LS at birth were analysed using a general least square procedure including these explanatory variables: breed group; age of ewe in years as a deviation from 3 years to the power of 1, 2 and 3 (regression); an effect of station and year; and an effect of breed group and year (to describe changes through years of the same breed group).

All effects of the model are highly significant except breed groups $\times$ year which is significant at the 0.05 level.

The least squares mean and mean lamb numbers are shown in table 2.

Figure 2 shows the least squares means 


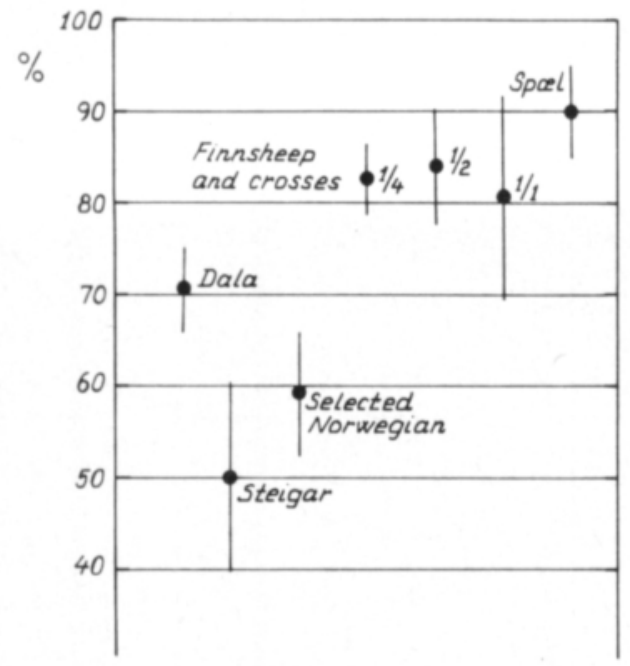

Fig. 1. Proportion of one year old ewes giving birth. (The bars show $+1-$ the approximate standard error of estimate.)

fitted by the model to a three year old ewe for each breed group and year.

Rather than an increase in lamb number over the years for the $\mathrm{N}$-breed group selected only for LS, there is a reduction through the five year period. Comparing this group to the relevant controls which are the $\mathrm{D}$ and $\mathrm{St}$ groups enforces this view.

The $1 / 2 \mathrm{~F}$ group also selected solely for LS fluctuates more through the years but neither for this can any increase in lamb number be detected through the five year period. Its relevant control is a combination of the $1 / 4 \mathrm{~F}$ group and the pure $\mathrm{F}$ group.

\section{Weaning weights of lambs}

The 7709 lambs with a recorded weaning weight averaged $41.6 \mathrm{~kg}$. The mean age at weighing was 150 days.

The weights were analysed with a model accounting for sex, breed group, age of lamb, age of dam, age of dam squared (regr.), station, year (regr.), age of lamb $\times$ breed group, year $\times$ breed group, year $\times$ station. All effects were found to be significant except year and year $\times$ breed group. The year $\times$ station effect was however highly singificant, indicat-

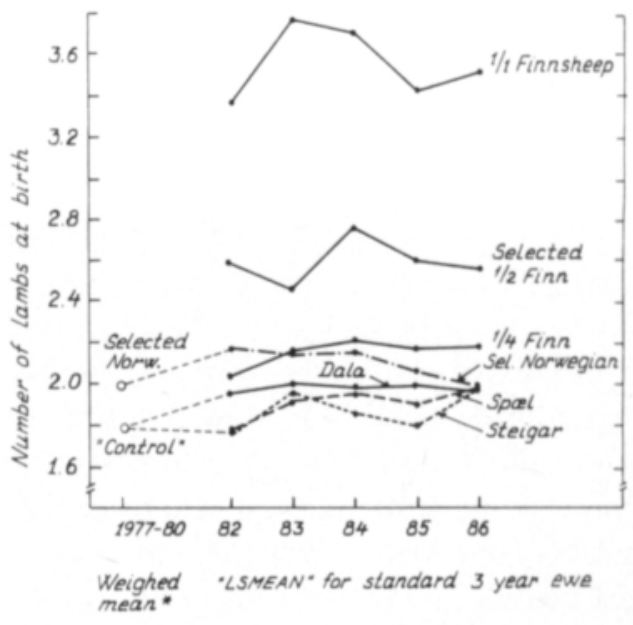

Fig. 2. Lambs at birth for 3 year old ewe. (The weighed mean* is for ewes 2 years old and more than 2 years old. LS-means are for 3 year old ewes accounting for age and station $\times$ year.)

ing a trend through the years different for the three stations.

The means and the least squares means for weaning weight for the different breed groups are shown in table 3 .

\section{Discussion}

After being established in the early 1970's the Selected $\mathrm{N}$-group $(\mathrm{N}+)$ had 0.2 lambs more per ewe than its controls (1). But through the last five years this seems to have been lost. In part this is probably due to the crossing in of $\mathrm{F}$ in the $\mathrm{N}$-breeds $\mathrm{D}$ and $\mathrm{St}$,

Table 3. Live weights of lambs.

\begin{tabular}{|c|c|c|c|c|}
\hline & \multicolumn{2}{|c|}{$\begin{array}{c}\text { Weaning weight, } \\
\mathrm{kg} .\end{array}$} & \multicolumn{2}{|c|}{$\begin{array}{c}\text { Lamb weaning } \\
\text { weight per ewe, } \\
\text { kg }\end{array}$} \\
\hline & LS-mean & Mean & LS-mean & Mean \\
\hline Dala & 43.5 & 43.3 & 71.3 & 71.3 \\
\hline Steigar & 43.7 & 45.3 & 63.1 & 63.4 \\
\hline Selected N & 41.4 & 41.5 & 69.5 & 71.9 \\
\hline $1 / 4 \mathrm{~F}$ & 42.6 & 43.1 & 80.0 & 82.6 \\
\hline Selected $1 / 2 \mathrm{~F}$ & 36.6 & 38.1 & 84.3 & 89.5 \\
\hline Finnsheep (F) & 32.0 & 33.8 & 91.4 & 96.8 \\
\hline Spæl & 38.9 & 40.6 & 67.6 & 71.7 \\
\hline
\end{tabular}


which here are the controls, thereby increasing their lamb numbers. In parts of Norway a high proportion of the ram lambs progeny tested have been of some F origin $(12-25 \%)$. When they are proven successful they are used in the breeding program (SANGOLT, 1988, personal communication). For 1969-72 the LS at birth for the three year old ewe of the D or St groups was around 1.75, whereas we now find 2.0 lambs for D and 1.85 for St (figure 2). Other explanations may be a small realised selection differential, inbreeding, or the breaking up of favourable epistatic effects. This has not been checked.

The $1 / 2 \mathrm{~F}$ group that also was selected for high lamb number gave in the last five years some 0.7 lambs more than the $\mathrm{N}$-ewes, whereas in 1969-72 this difference was around 0.5 lambs. The $1 / 4 \mathrm{~F}$ group shows the same increase in lamb number as the controls D and St, giving 0.25 lambs more both in 1969-72 and in 1982-86. It is therefore possible that selection in the $1 / 2 \mathrm{~F}$ group has had a positive effect. The amount of $\mathrm{F}$ in the group should, however, be checked to see if there has been a preference for those of the original ewes being more than $50 \% \mathrm{~F}$.

It is obvious that the amount of $\mathrm{F}$ in the synthetic lines influences the LS (figure 2). On the other hand the weaning weights decrease with a $\mathrm{F}$ increase. It is therefore not obvious which ewe produces most. Table 3 also gives a rough estimate of lamb weaning weight per ewe found by multiplying the proportion lambing, the lamb number and the weaning weight. We see that the pure $\mathrm{F}$ ewe produced $20-30 \mathrm{~kg}$ more lamb weaning weight, the $1 / 2$ F group $15-20 \mathrm{~kg}$ and the $1 / 4 \mathrm{~F} 10-15 \mathrm{~kg}$ more. In the 1969-72 period total production income per ewe (meat and wool, not calculat-

\section{References}

1. Steine, T. 1985. Genetic studies of reproduction in Norwegian sheep. In Land, R.B. and D.W. Robinson (Ed.). Genetics of Reproduction in Sheep. Butterworths, London: 47-54.

2. Steine, T.A., Vábenø, A.W., Bekken, A. \& Eikje, ing costs) was found to be $9 \%$ and $17 \%$ more for the $1 / 4$ and $1 / 2 \mathrm{~F}$-groups than for the N-groups. For the 1973-75 data the lamb carcass weight per ewe was found to be $20 \%$ and $25 \%$ more for the $1 / 4$ and 1/2 F-groups. Slaughter weight percentage of live weight was in the earlier data found to be $2-3 \%$ better for the $1 / 4$ and $1 / 2 \mathrm{~F}$ lines than for $\mathrm{N}$ sheep.

The results shown in table 3 favour the pure F. We have, however, no carcass evaluation. It was found earlier that the $1 / 2 \mathrm{~F}$ groups gave somewhat poorer carcass evaluation, and this is likely to be more so for the pure F. Our market requires carcasses above a minimum weight.

We use sheep to harvest our extensive mountain pastures in summer. To do this lambs should follow their dams and this becomes difficult with more than two lambs per ewe. Norwegian sheep farmers as a rule do not want surplus lambs. They want no more lambs than the ewes can handle on their own. Some, with many surplus lambs, have found it worthwhile to rear them artificially, and from a purely economical point of view this seems to be feasible. To see if it is possible to improve the milk production, we have imported (1985) semen of East Friesian Milk Sheep to try crossing this breed into Norwegian sheep.

Steine et al. (2) and Steine (1) concluded that $1 / 4 \mathrm{~F}$ should be recommended under our circumstances. We would, I think, from this last part of the experiment, conclude with a higher F proportion in our $\mathrm{N}$ sheep. But, taking into account that the conditions sheep are kept under may often not be as favourable as in the experiment, and the other points mentioned above, we are safe if we still recommend $25 \%$.
E.D. 1978. Resultat frå kryssingsforsøk med finsk landrase. (Results from a crossbreeding experiment with Finnsheep.) Scientific Rep. Agric. Univ. Norway. Vol. 57, No. 25: 21 pp. Engl. summ.

3. VÁbene, A.W., Bekken, A., Erı, John. \& Gjedrem, 
T. 1974. Resultater fra krysning mellom finsk landrase og norske saueraser. (Results from crossbreeding between Finnsheep and Norwegian sheep breeds.) Scien- tific Rep. Agric. Univ. Norway. Vol 53, No 17. 24 pp. Engl. summ. 